\title{
Corporate social responsibility and value creation
}

\author{
Professor Dr. Sorush Niknamian \\ Board Member of Weston A Price Foundation, Washington DC, USA \\ Email: so.niknamian@gmail.com
}

\begin{abstract}
Various studies have studied the effect of corporate social responsibility on the performance of organizations. The recent studies in this field specifically have considered the measurement of corporate social responsibility. The present study is aimed to measure the different dimensions of corporate social responsibility and their impact on the performance of firms based on economic value-added and cash value added. Based on the extensive concept of corporate social responsibility, to evaluate each of economic, legal and ethical dimensions, corporate social responsibility based on Carrol theory has applied a new method to quantify this qualitative concept. The statistical sample consists of 104 firms during 2007 to 2016. To test the study hypotheses, multi-variate regression model and pooled data methods are used. It was found that there was a positive and significant relationship between economic, legal and ethical dimensions of corporate social responsibility and value-added. It means that economic value added and cash value added are affected via corporate social responsibility in different dimensions and are increased.
\end{abstract}

Keywords: Corporate social responsibility, Value creation, Economic value-added, Cash value-added

\section{Introduction}

In recent years, the concept of corporate social responsibility has received much attention in academic and commercial environments. Although this concept is not a new idea for commercial organizations (Carroll, 1999) but the financial scandals in recent decades have received much attention from the investors, analysts and international institutes. This issue has changed the attitude to the managers of organizations. Considering the social commitment in determining the strategies of companies is of great importance and corporate social responsibility is turned into the dialogue between the organizations and society (Gray et al., 1995). This concept defines the process of the social and environmental effects of economic performance on the benefits of different groups in society. Thus, extensive responsiveness of organizations is included as beyond their traditional role in responding the owners of capita namely shareholders (Anas et al., 2015). In recent years, the corporate social performance is considered as a type of investment increasing the value of stockholders (Godfrey et al., 2009) and most of the global countries attempt to have 
a link with society via environment and social responsible actions to provide the valid brand and remove the barriers of sustainable long-term growth.

On the other hand, the necessity of organization success is its suitable performance. Different criteria are introduced to evaluate the performance of organizations, each one with special features. Now, evaluation of the performance of company based on value-oriented criteria, economic value-added, market valueadded, cash value-added (Bayrakdaroglu et al., 2012) fulfills the needs of different beneficiary groups. Thus, time value is created by which business units can cover all their operating and capital costs and the remaining is as profit (Talebnia and Shoja, 2011).

Based on the key role of corporate social responsibility in the growth and survival of company, the present study attempts to calculate the economic, ethical and legal dimensions of corporate social responsibility in accordance to Carrol (1991) theory based on accounting variables based on the constituting factors of each of dimensions in determining the efficiency coefficient of corporate social responsibility in Mosavi et a., (2016) model and extending its constituting factors independently. Innovation of this method is in using decimal ranking method to calculate combinational and comprehensive variable for each of variables based on Gaio and Raposo (2011) method in determining the combinational index of earnings quality. This combinational assessment method is not used in the calculation of the dimensions of corporate social responsibility in local and international researches. By considering the results of studies regarding the positive effect of corporate social responsibility on efficiency and performance of organizations, the effect and intensity of each of dimensions on economic value-added and cash value-added are evaluated a the value-based performance criteria.

\section{Corporate social responsibility}

Corporate social responsibility is an extensive term as defined by different methods. The academic and experts have attempted to present an accepted global description for this concept. Mohr et al., (2005) define corporate social responsibility as the firm commitment to minimize or eliminate any harmful effect of corporate activities on society and maximizing the long-term effects of the benefits of company on society. The concept of corporate social responsibility has been changed over time and by progress of communities and adjusting their expectations, it is changed again. Thus, there is no definition with global acceptance of this concept (Vyas and Raitani, 2015). The common feature in most of the definitions shows that corporate social responsibility enables the organizations to consider environmental and social issues in their policies and activities, some activities beyond maximizing profit to improve their effect on society (Galbreath \& Shum, 2012, Matten \& Moon, 2008). 
Presenting different definitions of corporate social responsibility indicates different views of various researchers. The pyramid model of Carrol is the most famous and acceptable concept in literature.

Carrol introduces the corporate social responsibility as the economic, legal, ethical and voluntarily expectations (humanitarian) as expected from the organizations by society.

Economic responsibility: Economic commitment is the first and most important dimension of corporate social responsibility as the companies should have income and attain profit for survival (Masoud, 2017). Based on this view, the organizations should do their social commitment to maximize profit. The companies not successful in financial and economic field, they exit trade and can not perform all their responsibilities. Thus, economic responsibility is a basic and initial necessity that should be fulfilled in a competitive commercial world (Carrol, 2016). Some indices including return on asset, return on equity, earnings per share and Q-Tobin indicate the economic commitments of organizations compared to shareholders and investors.

Legal responsibility: Based on this view, the organizations are obliged to observe the rules determined by the governments. In other words, the organizations should perform their economic activities in the framework of rules. The role of governments is supervisory and supports the groups not powerful in the activities and policies of organizations. The duty of organizations in this section is obeying the rules. The rules are imposed to control the social behavior of companies (Karim et al., 2016). Performing the regulation of corporate strategic system is observing the tax and insurance rules, suitable disclosure of information, lack of trading with dependent people are the indices expressing the legal commitment of organizations.

Ethical responsibility: Based on this view, the organizations are obliged to fulfil the expectations of society beyond the legal demands and needs as fair (Jonse, 2009). It means that the members of society expect that the organizations not only act based on the rules completely, but also they expect to do this process as clear and fair (Janamrung and Issarawornrawanich, 2015). Thus, commitment of company is respecting the values and norms of society.

Some concepts including justice, reality and fairness are the ethical issues that should be considered in formulating the strategies and selection of the procedures of company. Observing business ethics in organizations leads to the reduction of information asymmetry among the beneficiary groups and reduction of abnormal return due to presenting fair and clear information. The companies providing information and reports based on reality, fairness and justice concepts use low accruals in providing financial information (Rezayi and Ramezannia, 2017) and by reduction of the quality of accruals, the benefits of special groups are not preferred to the benefits of total beneficiaries. The lack of observing ethical principles by the organizations has some outcomes including losing reputation, reduction of sale and reduction of stock price. 


\section{Corporate social responsibility and firm's performance}

Different theories have investigated the relationship between corporate social responsibility and financial performance of firms and the most famous one is the agency theory (Levitt, 1958; Friedman 1970), stockholders (Freeman, 1984, Jones 1995), signaling (Connelly et al/. 2011). Agency theory states that the lack of strong control by the shareholders to control management causes that the managers use the resources of organization as opportunistically to increase their own benefits with the costs of shareholders. The resources of organization instead of investment in the projects creating value-added are used in achieving the goals including the personal benefits of managers (Arabsalehi et a., 2013).

On the other hand, the view of stockholders states that the organizations besides the shareholders have extensive relationship with different groups of stockholders (Freeman, 1984). The commercial activities of company can affect the welfare of most of stockholders including shareholders, employees, customers, suppliers, local communities, natural environment, government and public society. Each beneficiary group has different expectations from company. The good reaction to these expectations is vital for the present and future success of business enterprises (Aras and Crowther, 2008). Signaling theory is based on information asymmetry between two parties. The cause of asymmetrical information (deviation from complete information) is arising from the quantitative information or target information (Cannly et al., 2011). The signal of corporate social responsibility fulfills the demands of stockholders, avoids costly conflicts, improves the mutual relationship of stockholders and improves the business performance of company. In other words, better corporate social responsibility is a privilege improving the satisfaction of employees, reputation of companies and loyalty of customers and finally affects the results of company (Hart and Ahuja, 1996). Corporate social responsibility consumes the resources of organizations and affects their performance. Today, the companies are committed voluntarily to wide range of the activities of corporate social responsibility. The complex relationship between corporate social responsibility and corporate performance has received much attention by the academics. In the past decade, different studies have examined its effect on the firm's performance. Various researches have supported the positive impact of corporate social responsibility on corporate performance (Van Der Laan et al., 2008; Lin et al., 2009; $\mathrm{Wu} \&$ Shen, 2013). On the other $\mathrm{h}$ and, some studies have supported the negative relationship between corporate social responsibility and corporate performance (Lopez et al., 2007; Mittal et al., 2008). The negative relationship between corporate social responsibility and financial performance is consistent with the theories of Friedman and neoclassic economists. Friedman and his followers state that following the social goals affects the main goals of company and imposes extra costs on the organizations and can reduce the economic efficiency, competition and profitability (Alniacik et al., 2011). This view is against the view considering the social responsibility as the reason of improving financial performance, increase the value 
of company, reduce financial risk and information asymmetry, easy access to financial resources and reduced capital costs (Cho et al., 2013).

Researchers consider achieving different results based on different measures (Tanja et al., 2011), multidimensional structure of corporate social responsibility (Kang et al., 2016; Hull \& Rothenberg, 2008) and using measuring indices of difference performance (En Hou et al., 2017).

In the present study, the effect of economic, ethical and legal dimensions of corporate social responsibility on criteria of economic value-added and cash value-added is examined. Some of the relevant studies include:

Vahidi Elizai and Fakhari (2015) examined the effect of corporate social responsibility on financial performance of the companies listed on TSE. A questionnaire was applied to collect data from corporate social responsibility. The results of study supported a significant relationship between corporate social responsibility and financial performance of firms.

Tsoutsoura (2004) examined the relationship between corporate social responsibility and financial performance in American firms. The positive relationship with high significance between CSR and performance was supported.

Fomukong (2014) in a research examined the relationship between corporate social responsibility and economic value-added in oil and Gas industry of US and identified the performance differences and found that there was a positive and significant association between corporate social responsibility and economic value-added based on the theory of stockholders and pricing the capital assets.

Nollet et al., (2016) in a research "corporate social responsibility and financial performance" found that there was a negative and significant relationship between corporate social responsibility and return on capital. Also, the components of corporate governance system were effective on the relationship between social performance and financial performance of company. Onho et al., (2017) investigated the effect of corporate social responsibility on the performance of companies in innovative industries. Based on the results, social responsibility has a significant impact on creativity and innovation of these companies.

Wen and Song (2017) investigated the role of managers experienced in the economies of first world in improving the performance of social activities. The results showed that these managers applied CSR as a tool to present a good image to stockholders under the condition in which the organization is encountered with information asymmetry. Also, CSR can help the managers to reduce information asymmetry and increase firms' value.

\section{Study hypotheses}

The hypotheses of study are six as follows: 
First hypothesis: The economic dimension of corporate social responsibility has significant impact on economic value-added.

Second hypothesis: The ethical dimension of corporate social responsibility has significant impact on economic value-added.

Third hypothesis: The legal dimension of corporate social responsibility has significant impact on economic value-added.

Fourth hypothesis: The economic dimension of corporate social responsibility has a significant impact on cash value-added.

Fifth hypothesis: The ethical dimension of corporate social responsibility has a significant impact on cash value-added.

Sixth hypothesis: The legal dimension of corporate social responsibility has a significant impact on cash value-added.

\section{Variables of study}

The variables of study include three sets of independent, dependent and control variables as shown in Table 1.

Table 1- Variables of study

\begin{tabular}{|c|c|c|c|}
\hline Calculation method & Variable name & \multicolumn{2}{|c|}{ Type of variable } \\
\hline Net profit to assets ratio & Return on asset & \multirow{4}{*}{$\begin{array}{l}\text { Economic } \\
\text { dimension } \\
\text { of corporate } \\
\text { social } \\
\text { responsibili } \\
\text { ty }\end{array}$} & \multirow{5}{*}{$\begin{array}{l}\text { Independent } \\
\text { variable }\end{array}$} \\
\hline Ratio of net profit to equity & Return on equity & & \\
\hline Ratio of net profit to mean share & Earnings per share & & \\
\hline $\begin{array}{l}\text { Ratio of common share market value, book value of } \\
\text { preferred share and debts to total assets }\end{array}$ & Q-Tobin & & \\
\hline $\begin{array}{l}\text { Fairness }_{i . t}=1-\sigma\left(A R_{i . t}\right) \\
A R_{i . t}=R_{i . t}-E\left(R_{i . t}\right)\end{array}$ & Fairness & $\begin{array}{l}\text { Ethical } \\
\text { dimension }\end{array}$ & \\
\hline
\end{tabular}




\begin{tabular}{|c|c|c|}
\hline $\begin{array}{l}A R_{i . t} \text { هدز : Monthly Abnormal return on share of } \\
\text { company i }\left\{R_{i . t}: \text { Real monthly return on share of }\right. \\
\text { company i }\end{array}$ & & $\begin{array}{l}\text { of corporate } \\
\text { social } \\
\text { responsibili } \\
\text { ty }\end{array}$ \\
\hline $\begin{array}{l}\text { The type of report of auditors indicates observing } \\
\text { benefits of beneficiary groups from company. The } \\
\text { unqualified report fulfills the expectations of } \\
\text { different groups and disclaimer opinion indicates not } \\
\text { fulfilling the benefits of different groups. Also, the } \\
\text { quality of qualified report is determined based on the } \\
\text { number of its notes. }\end{array}$ & $\begin{array}{l}\text { Quality of auditor } \\
\text { opinion }\end{array}$ & \\
\hline 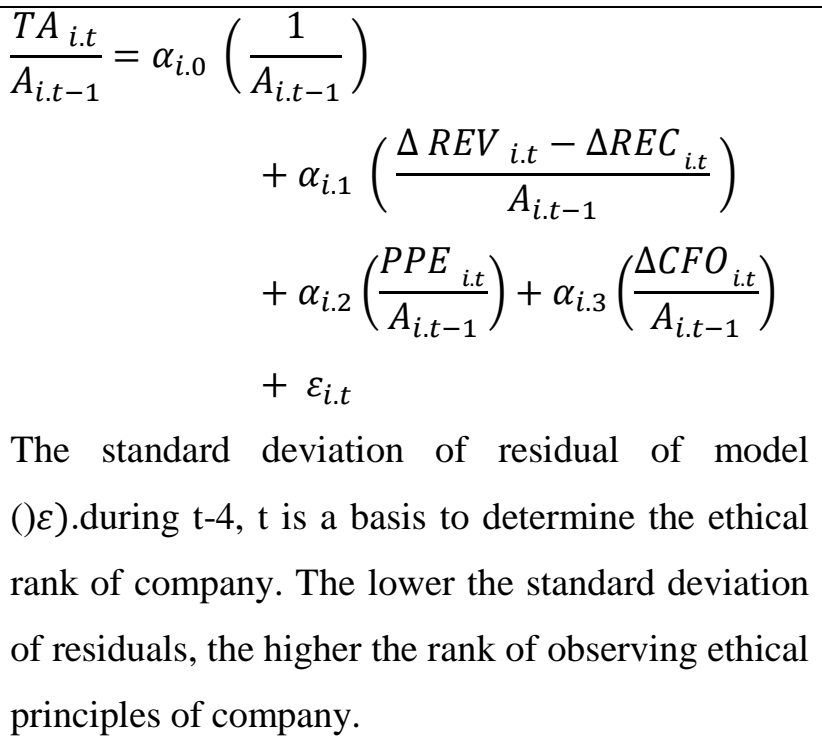 & Voluntarily accruals & \\
\hline $\begin{aligned} \frac{\text { TAC }_{i . t}}{\text { Assets }_{i . t-1}}= & \beta_{0 . i}+\beta_{1 . i}\left(\frac{\text { CFO }_{i . t-1}}{\text { Assets }_{i . t-1}}\right) \\
& +\beta_{2 . i}\left(\frac{\text { CFO }_{i . t}}{\text { Assets }_{i . t-1}}\right) \\
& +\beta_{3 . i}\left(\frac{\text { CFO }_{i . t+1}}{\text { Assets }_{i . t-1}}\right) \\
& +\beta_{4 . i}\left(\frac{\Delta \text { sales }_{i . t}}{\text { Assets }_{i . t-1}}\right) \\
& +\beta_{5 . i}\left(\frac{\text { PPE }_{i . t}}{\text { Assets }_{i . t-1}}\right)+v_{i . t}\end{aligned}$ & Quality of accruals & \\
\hline
\end{tabular}




\begin{tabular}{|c|c|c|}
\hline $\begin{array}{l}\text { Inverse of standard deviation of residual of model }) \varepsilon \text { ) } \\
\text { during } \mathrm{t}-4, \mathrm{t} \text { is a basis to determine the ethical rank } \\
\text { of company. } \\
\mathrm{AQ}=\frac{1}{\sigma\left(v_{i . t}\right)}\end{array}$ & & \\
\hline $\begin{array}{l}A s y=\frac{(A P-B P)}{\frac{(A P-B P)}{2}} * 100 \\
\text { Asy: The bid and ask range of share; AP: The mean } \\
\text { of proposed price of ask, BP is the mean proposed } \\
\text { price of bid }\end{array}$ & $\begin{array}{l}\text { Information } \\
\text { asymmetry }\end{array}$ & \\
\hline $\operatorname{LCETR}_{i . t}=\frac{\sum_{t=1}^{N} \text { Cash Tax } \text { Paid }_{i . t}}{\sum_{t=1}^{N} \text { Pre Tax } \text { Income }_{i . t}}$ & Tax avoidance & \multirow{5}{*}{$\begin{array}{l}\text { Legal } \\
\text { dimension } \\
\text { of corporate } \\
\text { social } \\
\text { responsibili } \\
\text { ty }\end{array}$} \\
\hline $\begin{array}{l}\text { The ratio of the number of non-executive managers } \\
\text { to tot number of board members }\end{array}$ & $\begin{array}{l}\text { Ratio of non- } \\
\text { executive members } \\
\text { of board }\end{array}$ & \\
\hline $\begin{array}{l}\text { Privilege of the given disclosure quality to each } \\
\text { company by TSE based on two criteria of timeliness } \\
\text { and reliability }\end{array}$ & Disclosure quality & \\
\hline $\begin{array}{l}\text { The ratio of costs of employer insurance to total } \\
\text { operating costs and costs of sold goods }\end{array}$ & $\begin{array}{l}\text { Insurance of } \\
\text { employer share }\end{array}$ & \\
\hline $\begin{array}{l}\text { Ratio of total trades with relevant people to the assets } \\
\text { of first period }\end{array}$ & $\begin{array}{l}\text { Trade with relevant } \\
\text { people }\end{array}$ & \\
\hline $\begin{array}{l}\mathrm{EVA}_{\mathrm{t}}=\mathrm{NOPAT}_{\mathrm{t}}-\mathrm{WACC}\left(\mathrm{Capital}_{\mathrm{t}-1}\right) \\
\text { NOPAT }_{\mathrm{t}} \text { :Net operating profit after tax deduction؛ } \\
\text { WACC }: \text { Weighted average capital cost. } \\
\text { Capital }_{\mathrm{t}-1} \text { : Total capital to book value at the } \\
\text { beginning of period } t .\end{array}$ & $\begin{array}{l}\text { Economic value- } \\
\text { added }\end{array}$ & \multirow[t]{2}{*}{ Dependent variable } \\
\hline $\begin{array}{l}\text { cash capital-operating cash profit after deducing tax } \\
\text { Operating cash profit after deducing tax=cash of } \\
\text { operating activities-paid tax }\end{array}$ & Cash value-added & \\
\hline
\end{tabular}




\begin{tabular}{|l|l|l|}
\hline Costs of cash capital=paid interest+ paid profit & & \\
\hline Natura logarithm of assets of company & Firm size & \\
\hline $\begin{array}{l}\text { Difference between the year of accepting company } \\
\text { and the study year }\end{array}$ & Age & \\
\hline Ratio of total debts to total assets & Leverage & \\
\hline $\begin{array}{l}\text { Percentage of change in sale for the current year to } \\
\text { the past year }\end{array}$ & Sale growth & \\
\hline
\end{tabular}

Model of study

Model 1 is selected to do testing hypotheses 1 to 3 and model 2 is used to do fourth to sixth hypotheses.

Model (1)

$$
\begin{gathered}
E V A_{i t}=\beta_{0}+\beta_{1}\left(E C O_{i t}\right)+\beta_{2}\left(E T H_{i t}\right)+\beta_{3}\left(L E G_{i t}\right)+\beta_{4}\left(S I Z E_{i t}\right)+\beta_{5}\left(A G E_{i t}\right)+\beta_{6}\left(L E V_{i t}\right) \\
+\beta_{7}\left(S G_{i t}\right)+\varepsilon_{i t}
\end{gathered}
$$

Model (2)

$$
\begin{gathered}
C V A_{i t}=\beta_{0}+\beta_{1}\left(E C O_{i t}\right)+\beta_{2}\left(E T H_{i t}\right)+\beta_{3}\left(L E G_{i t}\right)+\beta_{4}\left(S I Z E_{i t}\right)+\beta_{5}\left(A G E_{i t}\right)+\beta_{6}\left(L E V_{i t}\right) \\
+\beta_{7}\left(S G_{i t}\right)+\varepsilon_{i t}
\end{gathered}
$$

In each of models:

EVA: Economic value-added; CVA: Cash value-added, ECO: Economic dimension of corporate social responsibility; ETH: Ethical dimension of corporate social responsibility; LEG: Legal dimension of corporate social responsibility, SIZE: Firms size, AGE: Age of firm, LEV: Financial leverage, SG: Sale growth

\section{Results of study}

The results of descriptive statistics of study variables are shown in Table 2.

Table 2- Descriptive statistics of study variables 


\begin{tabular}{|l|l|l|l|l|l|}
\hline Max & \multicolumn{1}{l|l}{ Min } & \multicolumn{1}{l|}{ SD } & \multicolumn{1}{l|}{ Mean } & N & Variable \\
\hline $12 / 244$ & $-6 / 943$ & $2 / 251$ & $0 / 723$ & \multicolumn{1}{l|}{1040} & EVA \\
\hline $18 / 316$ & $18 / 319$ & $2 / 720$ & $0 / 265$ & 1040 & CVA \\
& - & & & & \\
\hline 10 & $1 / 25$ & $1 / 595$ & $5 / 250$ & 1040 & ECO \\
\hline $9 / 8$ & 3 & $1 / 057$ & $7 / 125$ & 1040 & ETH \\
\hline $9 / 6$ & $1 / 8$ & $1 / 133$ & $5 / 583$ & 1040 & LEG \\
\hline $0 / 998$ & $0 / 0179$ & $0 / 2005$ & $0 / 608$ & 1040 & LEV \\
\hline $19 / 066$ & $10 / 816$ & $1 / 449$ & $14 / 007$ & 1040 & SIZE \\
\hline $10 / 902$ & $-0 / 914$ & $0 / 589$ & $0 / 198$ & 1040 & SG \\
\hline $4 / 174$ & $2 / 079$ & $0 / 435$ & $3 / 514$ & 1040 & AGE \\
\hline
\end{tabular}

Before estimation of models, at first by performing chow, brush-Pagan and Hausman tests, a suitable estimation model of each model is defined. The results of test are illustrated in Table 3. In estimation of the models of study, the insignificance of chow statistics and Pagan brush for model 2, pooled effects model is used and insignificance of Hausman statistics for model lindicate that the mentioned model is estimated by using random effects model.

Table 3- The results of testing a good model selection of estimating models

\begin{tabular}{|l|l|l|l|l|l|l|}
\hline \multicolumn{2}{|l|}{ Hausman } & \multicolumn{2}{|l|}{ Brush-Pagan } & \multicolumn{2}{l|}{ Chow test } & $\begin{array}{l}\text { Studied } \\
\text { models }\end{array}$ \\
\cline { 1 - 6 } Significance & Statistics & Significance & Statistics & Significance & Statistics & Model \\
\hline $0 / 940$ & $2 / 31$ & $0 / 000$ & $404 / 43$ & $0 / 000$ & $12 / 18$ & 1 \\
\hline & & & & & & Model \\
& & $0 / 222$ & $0 / 58$ & $0 / 888$ & $0 / 48$ & 2 \\
\hline
\end{tabular}

\section{Results of testing hypotheses of study}

Table 4- The results of estimation of model 1 to test the first to third hypothesis

\begin{tabular}{|c|c|c|c|c|}
\hline \multicolumn{5}{|c|}{$\begin{array}{c}\mathrm{EVA}_{\mathrm{it}}=\beta_{0}+\beta_{1}\left(\mathrm{ECO}_{\mathrm{it}}\right)+\beta_{2}\left(\mathrm{ETH}_{\mathrm{it}}\right)+\beta_{3}\left(\mathrm{LEG}_{\mathrm{it}}\right)+\beta_{4}\left(\mathrm{SIZE}_{\mathrm{it}}\right)+\beta_{5}\left(\mathrm{AGE}_{\mathrm{it}}\right) \\
+\beta_{6}\left(\mathrm{LEV}_{\mathrm{it}}\right)+\beta_{7}\left(\mathrm{SG}_{\mathrm{it}}\right)+\varepsilon_{\mathrm{it}}\end{array}$} \\
\hline Statistics vif & Error level & T statistics & $\begin{array}{l}\text { Variable } \\
\text { coefficient }\end{array}$ & Variable \\
\hline
\end{tabular}




\begin{tabular}{|c|c|c|c|c|c|}
\hline & $0 / 000$ & $-7 / 23$ & $-9 / 086$ & \multicolumn{2}{|c|}{$\beta_{0}$} \\
\hline $1 / 34$ & $0 / 025$ & $2 / 24$ & $0 / 114$ & ECO & \\
\hline $1 / 06$ & $0 / 000$ & $7 / 34$ & $0 / 503$ & ETH & \\
\hline $1 / 19$ & $0 / 000$ & $4 / 08$ & $0 / 275$ & LEG & \\
\hline $1 / 37$ & $0 / 000$ & $4 / 08$ & $1 / 683$ & LEV & \\
\hline $1 / 19$ & $0 / 007$ & $2 / 68$ & $0 / 142$ & SIZE & \\
\hline $1 / 04$ & $0 / 001$ & $3 / 23$ & $0 / 395$ & SG & \\
\hline $1 / 01$ & $0 / 068$ & $1 / 83$ & $0 / 298$ & AGE & \\
\hline \multicolumn{4}{|l|}{$0 / 086$} & $\begin{array}{l}\text { Adjusted co } \\
\text { determination }\end{array}$ & efficient of \\
\hline \multicolumn{4}{|l|}{$0 / 002$} & $\begin{array}{l}\text { Wooldridge } \\
\text { probability }\end{array}$ & statistics \\
\hline \multicolumn{4}{|l|}{$0 / 963$} & $\begin{array}{l}\text { Wooldridge } \\
\text { probability }\end{array}$ & statistics \\
\hline \multicolumn{4}{|l|}{$97 / 13$} & \multicolumn{2}{|l|}{ F statistics } \\
\hline \multicolumn{4}{|l|}{$0 / 000$} & \multicolumn{2}{|c|}{ F statistics probability } \\
\hline \multicolumn{6}{|l|}{ Wald test } \\
\hline \multicolumn{2}{|c|}{$\begin{array}{l}\text { Comparison of coefficients } \\
\text { ECO with LEG }\end{array}$} & \multicolumn{2}{|c|}{$\begin{array}{l}\text { Comparison of coefficients } \\
\text { ETH with LEG }\end{array}$} & \multicolumn{2}{|c|}{$\begin{array}{llr}\text { Comparison } & & \text { of } \\
\text { coefficients } & \text { ETH with } \\
\text { LEG } & & \end{array}$} \\
\hline $\begin{array}{l}\text { Significance } \\
\text { coefficient }\end{array}$ & F statistics & $\begin{array}{l}\text { Significance } \\
\text { coefficient }\end{array}$ & F statistics & $\begin{array}{l}\text { Significance } \\
\text { coefficient }\end{array}$ & F statistics \\
\hline $0 / 0459$ & $3 / 993$ & $0 / 0478$ & $3 / 927$ & $0 / 000$ & $17 / 005$ \\
\hline
\end{tabular}

The first, second and third hypotheses based on the results on Table 4 from the estimation of model 1 are supported at the confidence interval 95\%. The positive coefficient of independent variables indicates their effect on increasing economic value-added. To investigate about the most effective dimension of corporate social responsibility on economic value-added, Wald test is applied to compare the coefficient of dimensions. Based on the results, ethical and legal dimensions had high effect significantly compared to economic dimension on economic value-added. Also, ethical dimension has high effect on value creation compared to legal dimension. 
Table 5- The results of estimation of model 2 to test fourth to sixth hypotheses

\begin{tabular}{|c|c|c|c|c|c|}
\hline \multicolumn{6}{|c|}{$\begin{array}{c}\mathrm{CVA}_{\mathrm{it}}=\beta_{0}+\beta_{1}\left(\mathrm{ECO}_{\mathrm{it}}\right)+\beta_{2}\left(\mathrm{ETH}_{\mathrm{it}}\right)+\beta_{3}\left(\mathrm{LEG}_{\mathrm{it}}\right)+\beta_{4}\left(\mathrm{SIZE}_{\mathrm{it}}\right)+\beta_{5}\left(\mathrm{AGE}_{\mathrm{it}}\right) \\
+\beta_{6}\left(\mathrm{LEV}_{\mathrm{it}}\right)+\beta_{7}\left(\mathrm{SG}_{\mathrm{it}}\right)+\varepsilon_{\mathrm{it}}\end{array}$} \\
\hline \multirow[t]{2}{*}{ Vif statistics } & \begin{tabular}{l|l} 
Error level \\
\end{tabular} & T statistics & $\begin{array}{l}\text { Variable } \\
\text { coefficient }\end{array}$ & Variable & \\
\hline & $0 / 001$ & $-3 / 47$ & $-4 / 994$ & \multicolumn{2}{|l|}{$\beta_{0}$} \\
\hline $1 / 34$ & $0 / 023$ & $2 / 28$ & $0 / 133$ & \multicolumn{2}{|l|}{ ECO } \\
\hline $1 / 06$ & $0 / 000$ & $5 / 08$ & $0 / 399$ & \multicolumn{2}{|l|}{ ETH } \\
\hline $1 / 19$ & $0 / 000$ & $4 / 34$ & $0 / 335$ & \multicolumn{2}{|l|}{ LEG } \\
\hline $1 / 37$ & $0 / 000$ & $-4 / 22$ & $-1 / 994$ & \multicolumn{2}{|l|}{ LEV } \\
\hline $1 / 19$ & $0 / 017$ & $2 / 38$ & $0 / 144$ & \multicolumn{2}{|l|}{ SIZE } \\
\hline $1 / 04$ & $0 / 235$ & $1 / 19$ & $0 / 166$ & \multicolumn{2}{|l|}{ SG } \\
\hline $1 / 01$ & $0 / 140$ & $-1 / 48$ & $-0 / 276$ & \multicolumn{2}{|l|}{ AGE } \\
\hline \multicolumn{4}{|l|}{$0 / 101$} & \multicolumn{2}{|c|}{$\begin{array}{l}\text { Adjusted coefficient of } \\
\text { determination }\end{array}$} \\
\hline \multicolumn{4}{|l|}{$0 / 329$} & $\begin{array}{l}\text { Wooldridge } \\
\text { probability }\end{array}$ & statistics \\
\hline \multicolumn{4}{|l|}{$0 / 580$} & $\begin{array}{l}\text { Wooldridge } \\
\text { probability }\end{array}$ & statistics \\
\hline \multicolumn{4}{|l|}{$115 / 27$} & \multicolumn{2}{|l|}{ F statistics } \\
\hline \multicolumn{4}{|l|}{$0 / 000$} & \multicolumn{2}{|c|}{ F statistics probability } \\
\hline \multicolumn{6}{|l|}{ Wald test } \\
\hline \multicolumn{2}{|c|}{$\begin{array}{l}\text { Comparison of coefficients } \\
\text { ECO with LEG }\end{array}$} & \multicolumn{2}{|l|}{$\begin{array}{l}\text { Comparison } \\
\text { coefficients } \\
\text { LEG }\end{array}$} & \multicolumn{2}{|c|}{$\begin{array}{l}\text { Comparison } \\
\text { coefficients } \text { ETH with } \\
\text { LEG }\end{array}$} \\
\hline $\begin{array}{l}\text { Significance } \\
\text { coefficient }\end{array}$ & F statistics & $\begin{array}{l}\text { Significance } \\
\text { coefficient }\end{array}$ & F statistics & $\begin{array}{l}\text { Significance } \\
\text { coefficient }\end{array}$ & $\begin{array}{l}\mathrm{F} \\
\text { statistics }\end{array}$ \\
\hline $0 / 0357$ & $4 / 421$ & $0 / 469$ & $0 / 523$ & $0 / 003$ & $8 / 437$ \\
\hline
\end{tabular}


Fourth, fifth and sixth hypotheses based on the results in Table 5 of estimation of model 2 are supported at confidence interval 95\%. The positive coefficient of independent variables indicates their effect on increasing cash value-added. To evaluate regarding the most effective dimension of corporate social responsibility, Wald test is used to compare the coefficient of dimensions. Based on the results, ethical and legal dimensions had high effect significantly compared to economic dimension on cash value added.

\section{Discussion and Conclusion}

Due to the vital role of corporate social responsibility in survival of organizations, many researches have investigated its effect on the performance of firms. The different researchers have applied different approaches to measure corporate social responsibility and each one views this item from a special angle. In this study, a comprehensive and combinational index is calculated for each of economic, ethical and legal dimensions of corporate social responsibility based on accounting criteria and decimal ranking method and the effect of each one on criteria of economic value-added and cash value-added as criteria of performance evaluation are investigated. The results of estimation of study models showed that economic, ethical and legal dimensions of corporate social responsibility had positive and significant effect on value creation of firms.

The management of commercial enterprises for their survival in the present competitive world is achieving high share of market, increase brand value, absorb loyal customers, using limited and valuable resources of society, being supported from government and legal organizations and having specialized forces. All these factors can lead to achieving profit, its continuance and value creation. According to the theory of beneficiaries, maximizing value of company to provide the resources of all beneficiary groups with different and contradictory requests can be considered. Observing rules on one hand and applying ethical procedures without legal requirement on the other hand can fulfill the different needs of beneficiaries.

Economic dimension of social responsibility indicates traditional expectations of economic enterprises. The increase of profitability indices can fulfill the economic responsibilities of companies and it has positive effect on value creation. Thus, first and fourth hypotheses are supported.

Information asymmetry arises from unfairness in identification, measurement or disclosure of information. If management and special groups of beneficiaries have special information not presented to the public, it can lead to deep information gap. Under these conditions, achieving benefit by special groups or people is 
with sacrificing the benefits of others groups. Also, the lack of observing ethical principles by managers in financial reporting can lead to dissemination of low quality information. One of the most important figures of financial statements is profit and it may be managed via voluntarily accruals or it doesn't have the required quality. This leaves the investors at loss as such companies don't perform their commitment and they lose suitable investment opportunity. Under such conditions, companies lose the trust of the public and the share of their market and can not create value. Thus, the positive effect of observing ethical principles by the managers of company on value creation in second and fourth hypotheses is supported.

Based on the separation of ownership, management and information asymmetry among them, the companies are obliged to disclose relevant information. According to signaling theory, disclosing high quality information by the companies indicates the positive condition and performance of company. Also, supervising the operation of commercial enterprises by the rules made by the governments and legal references can lead to optimal consumption of the resources of company to fulfill the benefits of beneficiary groups. Thus, the positive effect of observing rules by managers of company on value creation in third and sixth hypotheses is supported.

The results of study are consistent with the results of study of Vahidi Elizayi and Fakhari (2015), Tsoutsoura (2004) and Femukong (2014) and Vansung (2017) and are inconsistent with the results of Nowelt et al., (2016).

Based on the results of study, we can say from two different views about corporate social responsibility, the dominant approach in Iran supports the positive and effective role of corporate social responsibility on performance of firms. In other words, observing the social responsibility can reduce benefit conflict among managers and other groups of beneficiaries and by optima consumption of resources, can help the value maximization of shareholders. Based on the results, the companies can create value-added based on performing their commitment in all dimensions to fulfill the rights of all stockholders and it is the best factor in each organization in its sustainable growth.

Based on the positive effect of economic, ethical and legal dimensions of corporate social responsibility on value creation of companies, the managers should formulate their goals and strategies to fulfill the social commitments. Resorting to the social obligations can bring survival for the organizations. If the management of company observes ethical principles in using and selecting the accounting methods, the quality of information is increased and all stockholders share fairly in achieving the benefits of company. Also, the decision making governments and organizations by giving some privileges can encourage the organizations committed to social issues to internalize this norm by all business environments.

\section{References}


Rezayifarzin, Ramezannia, Hassan. 2017. The investigation of the effect of corporate social responsibility on systematic risk and non-systematic risk: Using envelope data analysis. Two journals of value and behavior accounting. Second year. NO. 4. 189-214.

Talebnia, Ghodratollah. Shojaesmail. 2011. The relationship between market value-added (MVA) to accounting profit and economic value-added (EVA) to accounting profit in the firms listed on TSE. Journal of management accounting. Fourth year. NO. 8. 47-60.

Arabsalehi, Mehdi; Sadeghi, Qazal, Moinoldin, Mahmoud. 2013. The relationship between corporate social responsibility and financial performance of the firms listed on TSE. Empirical researches of accounting. No. 9, 1-20.

Mosavi, Seyed Ahmad; Rezayi, Farzin, Shahveissi. Farhad. 2016. Explain the model of corporate social responsibility and its effect on the risk of stock price crash. Financial accounting knowledge. Period 3. No. 3. Serial 10, 47-74.

Vahidi Elizayi Ebrahim, Fakhari, Mandana. 2015. The effect of corporate social responsibility on financial performance of company. Accounting and audit researches. Year 7. NO. 27. 81-99.

Alniacik, Umit; Alniacik, Esra; and Genc, Nurullah.(2001). How Corporate Social Responsibility Information Influences Stakeholders' Intentions, Corporate Social Responsibility and Environmental Management, 18, $234-245$. (wileyonlinelibrary.com) DOI: 10.1002/csr.245

Anas , Abdirahman,. Abdul Rashid, Hafiz Majdi, and Annuar, Hairul Azlan . (2015). The effect of award on CSR disclosures in annual reports of Malaysian PLCs, Social Responsibility Journal, Vol. 11, Iss. 4, 831 - 852.

Aras G, Crowther D. (2008). The social obligation of corporations. Journal of Knowledge Globalization 1(1): 43-59. Bayrakdaroglu, Ali; Ersoy, Ersan; and Citak, Levent.(2012). Is There a Relationship Between Corporate Governance and Value-based Financial Performance Measures? A Study of Turkey as an Emerging Market, 41,pp 224-239. doi:10.1111/j.2041-6156.2012.01071.x

Carroll, AB. (1991). The Pyramid of Corporate Social Responsibility: Toward the Moral Management of Organizational Stakeholders . Business Horizons, Vol. 34, 39-48.

Carroll AB. (1999). Corporate social responsibility: Evolution of a defi nitional construct. Business and Society 38(3): 268-295.

Carroll, AB.(2016). Carroll's pyramid of CSR: taking another Look, International Journal of Corporate Social Responsibility, Vol. 1 No. 3, pp. 1-8. DOI 10.1186/s40991-016-0004-6

Cho, S. Y., Lee, C., and Pfeiffer, R. J. (2013). Corporate social responsibility performance information and information asymmetry. Journal of Accounting and Public Policy, 32(1), 71-83.

Connelly, B. L.; Certo, S. T.; Ireland, R. D.; and C.R. Reutzel. (2011). "Signaling theory: A review and assessment", Journal of Management, No.37,pp. 39-67.

En Hou, Chen., Min Lu, Wen., and Wan Hung, Shiu .(2017). Does CSR matter? Influence of corporate social responsibility on corporate performance in the creative industry, Annals of Operations Research, 1-25, DOI 10.1007/s10479-017-2626-9.

Fomukong,j. (2014). Relationship between Corporate Social Responsibility and Economic Value Added from the Oil and Gas Industry Perspective, Doctoral thesis, Walden University, 1-175.

Freeman, R. (1984). Strategic management: A stakeholder perspective. Englewood Cliffs, NJ: Prentice-Hall.

Friedman, M. (1970). The social responsibility of business is to increase its profits. New York Times, September 13. Gaioa, Cristina and Clara, Raposo. (2011). Earnings quality and firm valuation: international evidence, Accounting and Finance, Vol. 51, 467-499. 
Galbreath, J., \& Shum, P. (2012). Do customer satisfaction and reputation mediate the CSR-FP link? Evidence from Australia. Australian Journal of Management, 37(2), 211-229. https:// doi. org/ 10.1177/0312896211432941

Godfrey, P.C., Merrill, C.B. and Hansen, J.M. (2009).The relationship between corporate social responsibility and shareholder value: an empirical test of the risk management hypothesis, Strategic Management Journal, Vol. 30 No. 4, pp. 425-445.

Gray, R.H., Kouhy, R. and Lavers, S. (1995b), "Constructing a research database of social and environmental reporting by UK companies: a methodological note”, Accounting, Auditing \& Accountability Journal, Vol. 8 No. 2, pp. 78 -101. Hart, S. L., and G. Ahuja. (1996). Does it pay to be green? An empirical examination of the relationship between emission reduction and firm performance, Business Strategy and the Environment,No. 5,pp 30-37.

Hull, C. E., \& Rothenberg, S. (2008). Firm performance: The interactions of corporate social performance with innovation and industry differentiation. Strategy Management Journal, 29(7), 781-789.

Janamrung, B. ; Issarawornrawanich, Panya .(2015). The association between corporate social responsibility index and performance of firms in industrial products and resources industries: empirical evidence from Thailand, SOCIAL RESPONSIBILITY JOURNAL, 11(4): 893-903.

Jones, Brian,. Bowd, Ryan and Tench, Ralph .( 2009). Corporate irresponsibility and corporate social responsibility: competing realities, SOCIAL RESPONSIBILITY JOURNAL,5(3), 300-310.

Jones, T. (1995). Instrumental stakeholder theory: A synthesis of ethics and economics. Academy of Management Review, 20, 404-437.

Kang, C., Germann, F., \& Grewal, R. (2016). Washing away your sins? Corporate social responsibility, corporate social irresponsibility, and firm performance. Journal of Marketing, 80(2), 59-79.

Karim, Khondkar., Hyun, Sang,. And Tang, Suh Jiali .(2016). Do ethical firms create value?, Social Responsibility Journal, Vol. 12, Iss.1, $54-68$.

Levitt, T. 1958. The dangers of social responsibility. Harvard Business Review, 36, 41-50.

Lin, C., Yang, H., \& Liou, C. (2009). The impact of corporate social responsibility on financial performance: Evidence from business in Taiwan. Technology in Society, 31, 56-63.

Lopez, M. V., Garcia, A., \& Rodriguez, L. (2007). Sustainable development and corporate performance: A study based on the Dow Jones sustainability index. Journal of Business Ethics, 75(3), 285-300.

Masoud, N .(2017). How to win the battle of ideas in corporate social responsibility: the International Pyramid Model of CSR, International Journal of Corporate Social Responsibility, Vol. 2, No. 4. DOI 10.1186/s40991-017-0015-y

Matten, D., \& Moon, J. (2008). "Implicit" and "Explicit" CSR: A Conceptual Framework for a Comparative Understanding of Corporate Social Responsibility. Academy of Management Review, 33(2), 404-424. https://doi.org/10.5465/AMR.2008.31193458

Mittal RK, Sinha N, Singh A (2008) An analysis of linkage between economic value added and corporate social responsibility. Manag Decis 46(9):1437-1443

Mohr LA, Webb DJ.( 2005). The effects of corporate social responsibility and price on consumer responses. The Journal of Consumer Affairs 39(1): 121-147.

Nollet, Joscha., Filis , George., and Mitrokostas , Evangelos .(2015).Corporate social responsibility and financial performance: A non-linear and disaggregated approach, Economic Modelling, Available online 19 October 2015.

Taneja, S. S., Taneja, P. K., and Gupta, R. K.( 2011). Researches in corporate social responsibility: A review of shifting focus, paradigms, and methodologies. Journal of Business Ethics, 101(3), 343-364.

Tsoutsoura, M,. (2004). Corporate social responsibility and financial performance, University of California at Berkeley, financial project.

Van Der Laan, G., Van Ees, H., \& Van Witteloostuijin, A. (2008). Corporate social and financial performance: An extended stakeholder theory and empirical test with accounting measures. Journal of Business Ethics, 79(2), 299-310. Vyas, V., and Raitani, S. (2015). An examination of linkages between CSR and cross-buying. Social Responsibility Journal, 11(3), 622-640.

Wen, Wen., and Song, Jianbo. (2017). Can returnee managers promote CSR performance? Evidence from China, Frontiers of Business Research in China,11:1-26. DOI 10.1186/s11782-017-0012-8.

Wu, M., \& Shen, C. (2013). Corporate social responsibility in the banking industry: Motives and financial performance. Journal of Banking and Finance, 37, 3529-3547. 
